\title{
Hereditary anhidrotic ectodermal dysplasia
}

\section{Studies in a Nigerian family}

\author{
J. B. FAMILUSI, F. JAIYESIMI, C. O. OJO, and ED. 'B. ATTAH \\ From the Department of Paediatrics and Pathology, University College Hospital, Ibadan, Nigeria
}

Familusi, J. B., Jaiyesimi, F., Ojo, C. O., and Attah, Ed. 'B. (1975). Archives of Disease in Childhood, 50, 642. Hereditary anhidrotic ectodermal dysplasia: studies in a Nigerian family. Studies in a Nigerian family with hereditary anhidrous ectodermal dysplasia are reported. Microscopical examinations of finger tips for sweat pores were diagnostic in phenotypes, and it is suggested that this simple nonsurgical procedure is a preferred alternative to skin biopsies in the diagnosis of the syndrome. The clinical implications of a tropical environment for the syndrome, as well as the factors that may favour maintenance of the gene in such an environment are discussed.

Hereditary anhidrotic ectodermal dysplasia (HAED) is a rare disease characterized by nondevelopment or underdevelopment of certain ectodermal structures, namely, the skin and its appendages and the teeth. Clinically there is anhidrosis, hypodontia, and hypotrichosis (Weech, 1929; Upshaw and Montgomery, 1949; Lorber, 1964). Other features include characteristic facies with protruding thick lips, large deformed ears, broad depressed bridge of nose, and frontal bossing (Upshaw and Montgomery, 1949; Gorlin and Pindborg, 1964; Blattner, 1968). Inheritance is usually determined by an X-linked recessive gene (Weech, 1929; Wilkey and Stevenson, 1945; Kerr, Wells, and Cooper, 1966). The present communication describes this syndrome in a Nigerian family. As far as we can ascertain there has been no previous report of the syndrome in Africans. This report includes physiological investigations of sweating, and histopathological examination of skin biopsies and sweat pores.

\section{Case reports}

Case 1. The propositus, a Nigerian boy, first came under our care at University College Hospital, Ibadan, in August 1972 at the age of $2 \frac{1}{2}$ years. The immediate problem was a 10-day history of fever, cough, anorexia, and nasal discharge. Pregnancy and delivery were both uneventful, but his parents had noted him to be markedly intolerant of heat since birth. He became hot in the afternoons and had to be regularly cold-sponged.

Received 23 December 1974.
He was always uncomfortable sleeping in a bed, preferring the cold floor, and never used a blanket. He had never been seen to sweat. Apart from the intolerance to heat, the only other past medical problem was recurrent rhinitis.

Physical examination revealed a thinly-built male child weighing $10.4 \mathrm{~kg}$. He was febrile, the temperature on admission being $39^{\circ} \mathrm{C}$. The scalp hair was fine, straight, and scanty; eyelashes were sparse, and eyebrows were completely absent. The nose was saddleshaped with a very depressed bridge. The lips were thick and everted (Fig. 1A). There was complete absence of teeth and the jaw bones were hypoplastic to palpation. The skin was thin and dry. There was moderate clubbing of the fingers. There were no abnormalities detected on examination of the respiratory, cardiovascular, and central nervous systems. His

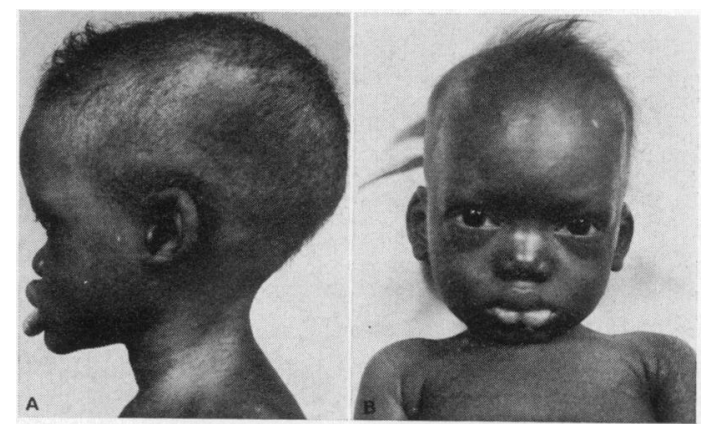

Fig. 1.- (A) The propositus at age $3 \frac{1}{2}$ years. (B) Affected younger brother at age 8 months. Note fine scanty straight hair and thick everted lips. 
TABLE

Genetic and immunological data on family

\begin{tabular}{|c|c|c|c|c|c|c|}
\hline & \multirow{2}{*}{$\begin{array}{l}\text { G-6-P D } \\
\text { genotype }\end{array}$} & \multirow{2}{*}{$\begin{array}{l}\text { Haemoglobin } \\
\text { genotype }\end{array}$} & \multirow{2}{*}{$\begin{array}{l}\text { Ectodermal } \\
\text { dysplasia }\end{array}$} & \multicolumn{3}{|c|}{$\begin{array}{l}\text { Immunoglobulins ( } \% \text { of } \\
\text { normal Nigerian content) }\end{array}$} \\
\hline & & & & $\operatorname{Ig} \mathbf{A}$ & $\operatorname{Ig} M$ & $\mathrm{IgG}$ \\
\hline $\begin{array}{l}\text { Propositus } \\
\text { Affected sib } \\
\text { Unaffected sib } \\
\text { Mother } \\
\text { Father }\end{array}$ & $\begin{array}{c}\mathrm{Gd}^{\mathrm{B}} \\
\mathrm{Gd}^{\mathrm{B}} \\
\mathrm{Gd}^{\mathrm{B}} \\
\mathrm{G}^{\mathbf{B}} / \mathrm{Gd}^{\mathrm{B}} \\
\mathrm{Gd}^{\mathbf{A}}\end{array}$ & $\begin{array}{l}\text { AA } \\
\text { AA } \\
\text { AA } \\
\text { AA } \\
\text { AA }\end{array}$ & $\begin{array}{l}\text { Phenotype } \\
\text { Phenotype } \\
\text { Normal } \\
\text { Heterozygote } \\
\text { Normal }\end{array}$ & $\begin{array}{l}133 \\
128 \\
118 \\
103 \\
210\end{array}$ & $\begin{array}{r}103 \\
90 \\
115 \\
145 \\
125\end{array}$ & $\begin{array}{r}55 \\
45 \\
130 \\
110 \\
90\end{array}$ \\
\hline
\end{tabular}

intelligence, using the Denver developmental screening scale (Frankenburg and Dodds, 1969), was normal for his age.

Laboratory investigations showed packed cell volume $31 \%$; leucocytes $6400 / \mathrm{mm}^{3}$ with normal differentials; haemoglobin electrophoresis showed HbA only, and glucose-6-phosphate dehydrogenase (G-6-PD) level was normal. Blood smear examination showed no malaria parasites, and bacteriological cultures of blood and urine yielded no pathogens. Serological reactions for syphilis were negative. Serum immunoglobulin estimations showed normal level of IgM, moderately raised level of IgA, but a very low level of IgG compared with normal Nigerian population (Table). $X$-rays of the jaws showed hypoplasia of the mandibles and complete absence of tooth buds (Fig. 2).

He was treated symptomatically with cold sponging

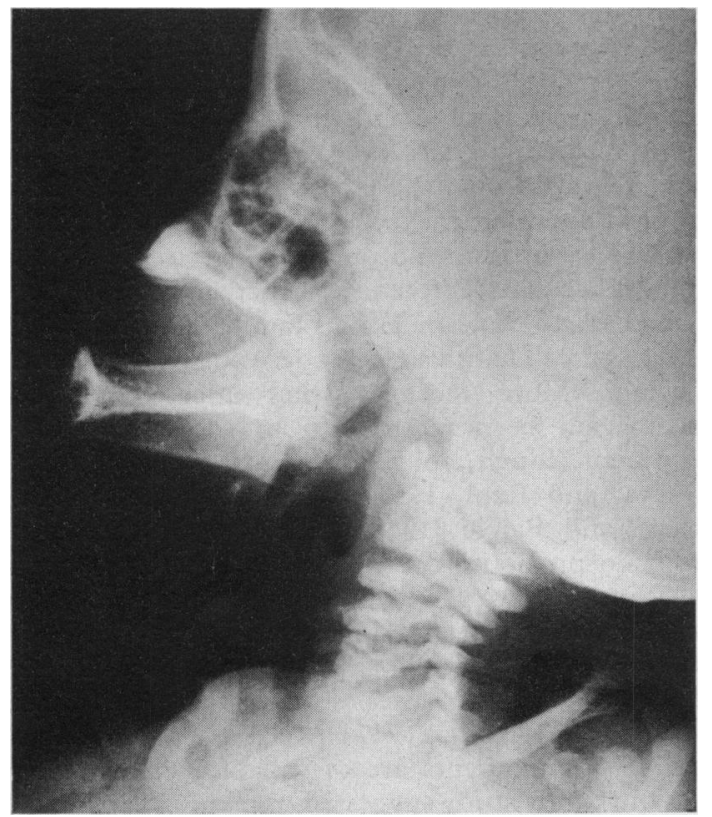

FIG. 2.-X-ray of jaw bones of propositus. Note absence of teeth and tooth buds. and soluble aspirin, and his fever subsided over the following 24 hours. When the diagnosis of anhidrotic ectodermal dysplasia was subsequently established, the implications were explained to his parents. At the time of writing he remains well, but needs to avoid hot environments. On hot afternoons he demands frequent cold baths.

Case 2. A younger brother of the propositus, aged 8 months, was discovered during a family study conconducted in September 1973 when diagnosis of HAED in the propositus was confirmed. He had the same physical features as the propositus (Fig. 1B), was similarly pyrexial on hot afternoons, and prone to frequent upper respiratory tract infections. Laboratory investigations showed normal values for haematocrit, white cell counts, and serum electrolytes and urea. Haemoglobin and G-6-PD genotypes, as well as the immunoglobulin profile, were identical with those of the propositus (Table). Microbiological examinations of urine, blood, and stools showed no pathogens. Serological tests for syphilis were negative.

$\mathrm{He}$ thrived well during the following 2 months. Unfortunately, however, a febrile illness for which he was not immediately brought to hospital resulted in his death in December 1973.

Family study. The parents of the probands denied consanguinity, but they both come from a village about 60 kilometers from Ibadan in Western Nigeria. The family pedigree is shown in Fig. 3. The mother had had 9 children altogether, but only 3 of these were alive at the time of the family study, the 2 patients described above, and one normal brother aged 9 years. 3 other male children who died at ages 1 year, 10 months, and 3 months, respectively, were recognized by the parents to have had physical features strongly suggestive of HAED. All died of hyperpyrexia. One apparently unaffected male died after an attack of measles, and 2 females, also unaffected, died during febrile convulsive episodes. The father had no features of the disease, but the mother had scanty hair and malformed dentition (Fig. 4). She, however, did not complain of heat intolerance. A deceased maternal great-uncle of the affected children reportedly had complete features of the disease. All the grandparents had died and no clinical information was available about 


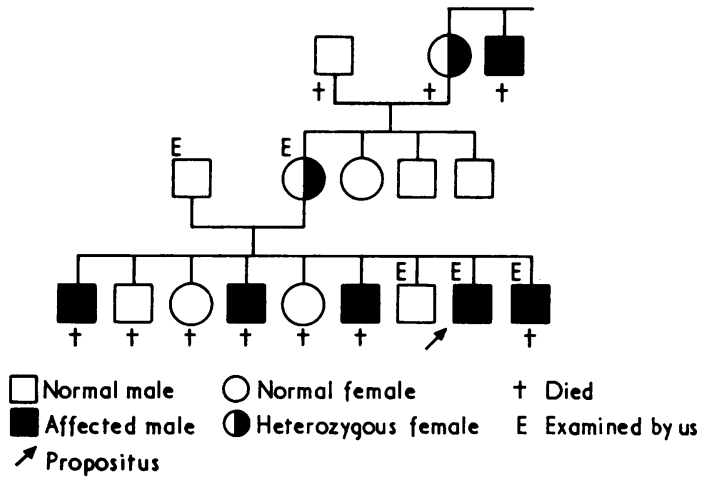

FIG.-3. Pedigree of family.

them. It should be noted, however, that the maternal grandmother was an obligate heterozygote for HAED (Fig. 3).

\section{Other investigations}

Examination for sweat pores.

Method. Impressions of finger tips were made by a modification of the method described by Crump and Danks (1971). The finger tips were painted with a solution containing $2 \%$ cellulose acetate and $0.35 \%$ crystal violet in acetone and allowed to dry. 2 thin layers of $2 \%$ cellulose acetate in acetone were then applied with a brush, and the thin films formed were stripped off the finger tips with cellotape adhesives. This was mounted with the impression side uppermost on a microscope slide and examined at $\times 150$ magnification. The probands, both parents, and the only sur-

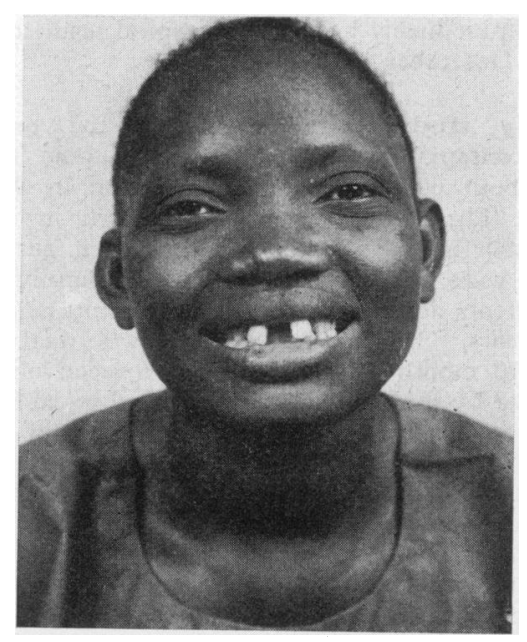

Fig. 4.-Defective dentition and scanty hair in heterozygote mother. viving unaffected sib were studied. 5 normal controls matched for age and sex were also studied.

Results. The probands had hypoplastic dermal ridges and no sweat pores (Fig. 5A). Sweat pores were present in numbers comparable to normal controls in their unaffected brother and father (Fig. 5B) while their mother had scanty sweat pores.

Examination of skin sections. Biopsy specimens obtained from the outer surface of the forearms were examined for sweat glands and other skin appendages. There was complete absence of sweat glands and other adnexae in the probands (Fig. 6A) while the mother had scanty amounts of these. The normal relatives had normal complements of all skin appendages (Fig. 6B).

Sweat test. $5 \mathrm{mg}$ pilocarpine injected subcutaneously failed to produce any sweating in the propositus. The same dose of pilocarpine administered to a normal 3-year-old boy (control) produced profuse sweating. Sweat test was not performed on the second patient because published reports indicated that it is potentially dangerous in children with HAED (Lorber, 1964).

\section{Discussion}

The occurrence of hereditary anhidrotic ectodermal dysplasia in an indigenous tropical African family is of clinical and genetic interest. The defective sweating in this syndrome prevents adequate thermal regulation and predisposes to hyperpyrexia. Febrile seizures, brain damage, and death in early life may result from exposures to hot environments (Drago and Ehrenreich, 1961; Mills, 1968; Capitanio et al., 1968). Survival of children with the syndrome therefore appears unlikely in a tropical environment, though the well-documented occurrence of the syndrome in some tropical areas contradicts this inference. Thadani (1921) described many cases in Hindu families around Sind, India, while De Silva (1939) described 4 cases from Ceylon. More recently other affected families have again been reported from the Indian subcontinent (Singh, Jolly, and Kaur, 1962; Mathur, Gupta, and Rahl, 1967; Gupta and Ram, 1968; Misra and Bajpai, 1969). There have, however, been no previous reports of HAED in indigenous Africans. A search of published reports revealed 2 previous cases in American Negroes both of whom were of mixed ancestry with evidence of inheritance of the disease from white ancestors (Capper and Bekir, 1937; Metson and Williams, 1952). Our patients are of full Negroid ancestry and the family study suggested transmission through at least two generations. The probability thus exists that Africans with the syndrome have hitherto 


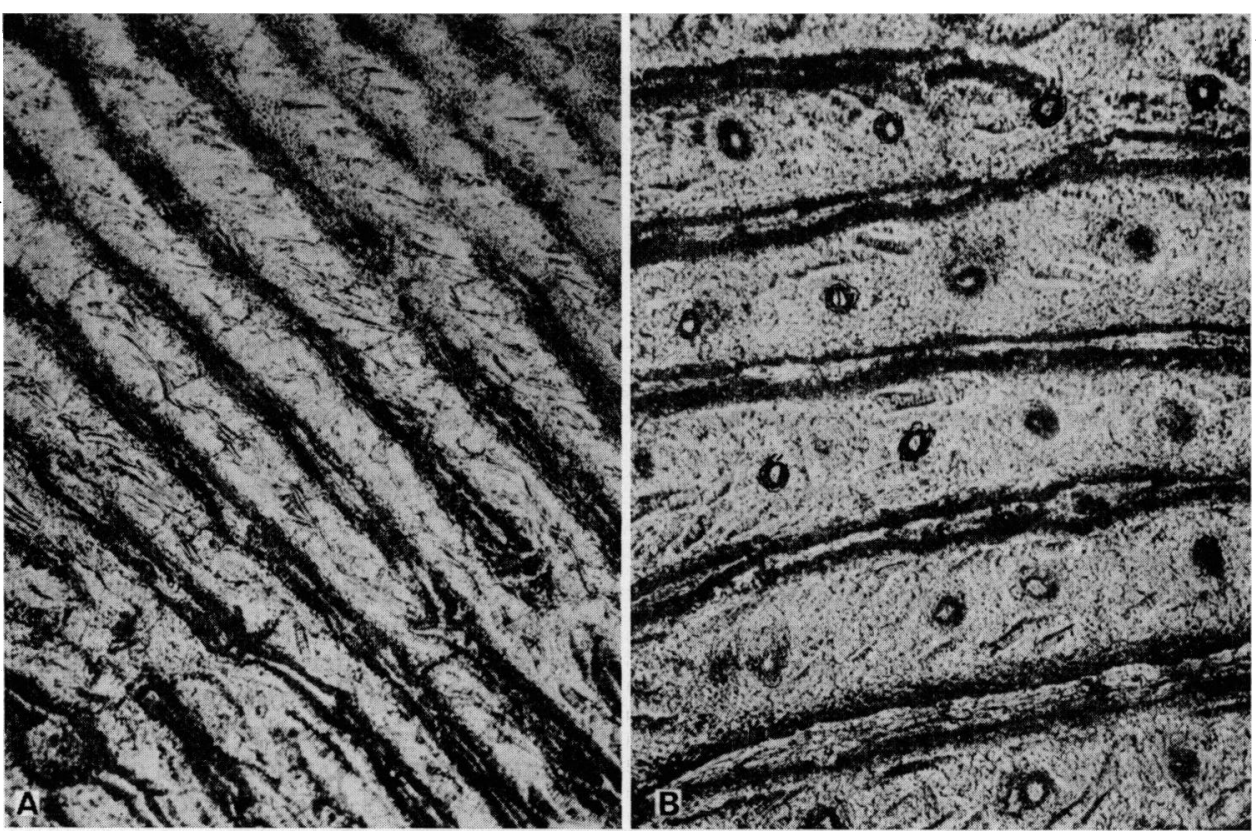

FIG. 5.-Photomicrographs of dermal ridges. $(\times 110)$. (A) Propositus with hypoplastic ridges without sweat pores. (B) Normal dermal ridges and sweat pores.
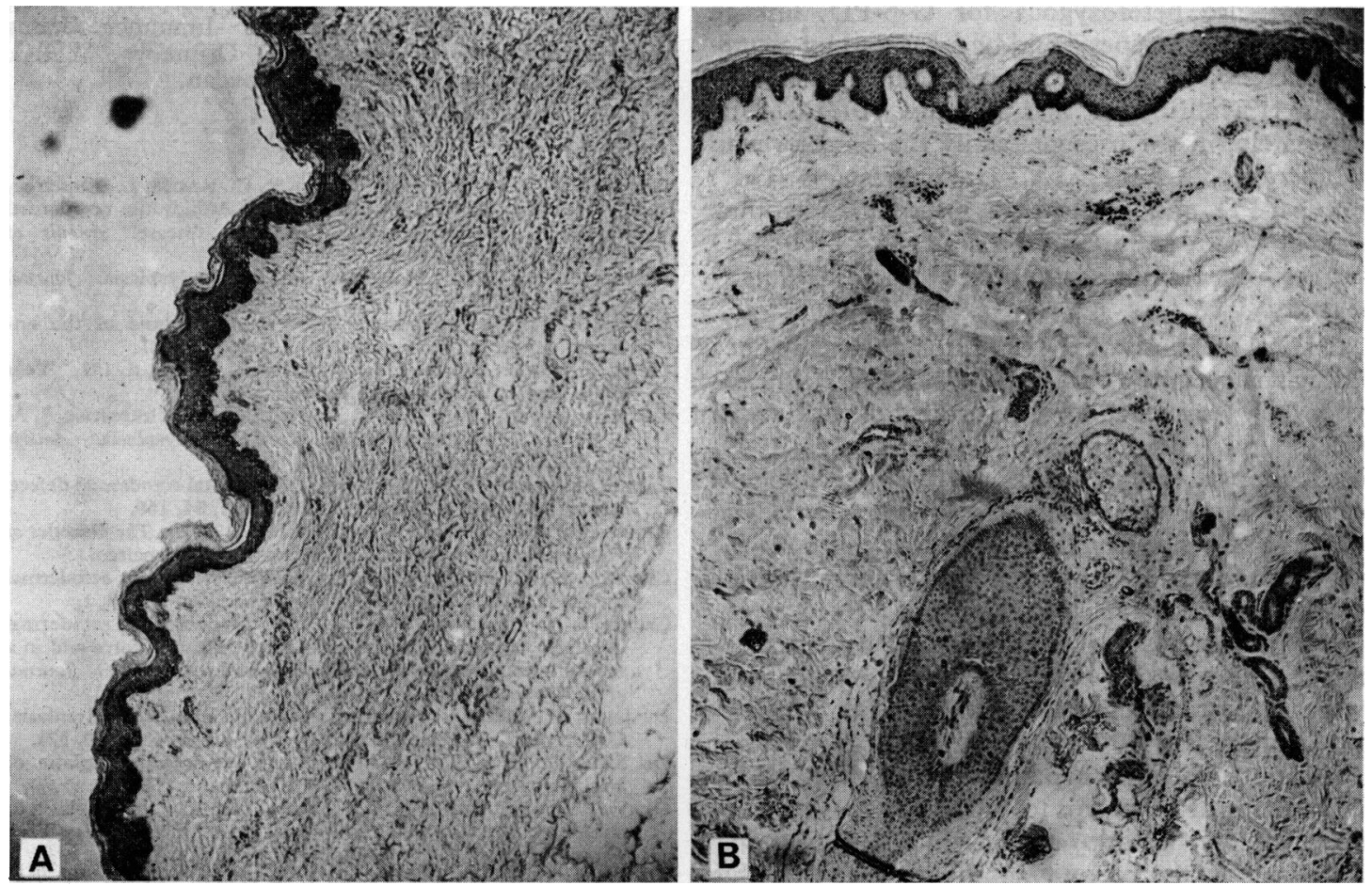

Fig. 6.-Photomicrographs of skin biopsies. $H \in E \times 70)$. (A) Propositus showing total lack of skin adnexae. (B) Father of propositus showing normal compliments of skin adnexae. 
been undiagnosed because of inadequate diagnostic facilities.

There is as yet no information on how the gene for HAED is maintained in a tropical environment. In general one would expect that selection against the male phenotype should be more severe in a hot climate than in a temperate one. However, since the heterozygous female carriers are minimally affected clinically, the abnormal gene might be maintained by them at whatever frequency it exists in the population. Also it is theoretically possible that the carrier female enjoys some sort of heterozygote advantages, for example, by virtue of $\mathrm{X}$-chromosome inactivation mosaicism (Lyon, 1971). Such a possibility was indeed suggested by the patchy distribution of sweat pores in the heterozygote females studied by Passarge and Fries (1973). If a suitable test became available for screening of heterozygotes, determination of the gene frequencies in various communities could help to assess how this mutation affects biological fitness as a function of the environment. The possibility of linkages between the gene for HAED and other sex-linked genes (e.g. G-6-PD, for which a screening test is available) is worthy of study in this regard. Thus, if a heterozygous female for HAED is for example also heterozygous for G-6-PD, linkage between the two genes could be measured by counting recombinants and nonrecombinants in offspring (Cavalli-Sforza and Bodmen, 1971). Unfortunately, in the present family the mother, who is heterozygote for HAED, is homozygous $\left(\mathrm{Gd}^{\mathrm{B}}\right)$ for G-6-PD and no linkage information is thus available from members tested (Table). G-6-PD status of other families with HAED would be worthy of study.

Clinical diagnosis of HAED is relatively easy once physicians become aware of the syndrome. Phenotypes look very much alike regardless of their racial background (Upshaw and Montgomery, 1949; Reed, Lopez, and Landing, 1970). Radiological features of the disease are also characteristic and consist of absence or marked deficiency of both the primary and secondary tooth buds (Lowry, Robinson, and Miller, 1966; Caffey, 1967; Reed et al., 1970). Diagnosis may be confirmed by examination of skin biopsies which will show deficiency of sweat glands and other skin appendages (Upshaw and Montgomery, 1949; Clouston, 1939; Reed et al., 1970), but this is perhaps now better replaced by examination of finger tips for sweat pores, as recently described by Crump and Danks (1971). Our experience in the present family suggests that this simple, nonsurgical technique is of comparable diagnostic value to examination of skin biopsies.
The greatest threat to life in HAED is hyperpyrexia on exposure to hot environments (Lipton and Roberts, 1950; Lowry et al., 1966; Mills, 1968). Though the absence of mucous glands in the respiratory tract predisposes these children to respiratory infections (Clouston, 1939; De Jager, 1965), with the advent of antibiotics and chemotherapeutic agents many now survive such infections (Metson and Williams, 1952). The low IgG levels found in our 2 patients may also predispose to recurrent infections but hypo- $\gamma$-globulinaemia is not a constant feature of HAED (Capitanio et al., 1968). Survival of children with HAED therefore is largely dependent on avoidance of exposure of the children to hot environments. Heat prostration becomes a lesser threat if the patients survive early childhood, for experience will teach them to avoid hot environments or keep their clothes moist in hot weather in order to keep cool (Bowen, 1932; Lowry et al., 1966). Provided such precautions are observed, life expectancy in HAED is good and patients surviving to middle and old age have been described (Beahrs et al., 1971).

We thank Professors A. U. Antia and L. Luzzatto for helpful criticism of the manuscript, and the Medical Illustration unit, University College Hospital, Ibadan, for help with the illustrations. Immunoglobulins were estimated by Professor B. O. Osunkoya, W.H.O. Immunology Unit, University of Ibadan.

\section{REFERENCES}

Beahrs, J. O., Lillington, G. A., Rosan, R. C., Russin, L., Lindgren, J. A., and Rowley, P. T. (1971). Anhidrotic ectodermal dysplasia: predisposition to bronchial disease. Annals of Internal Medicine, 74, 92.

Blattner, R. J. (1968). Hereditary ectodermal dysplasia. Fournal of Pediatrics, 73, 444.

Bowen, R. (1932). Hereditary ectodermal dysplasia of the anhidrotic type. Southern Medical fournal, 25, 481.

Caffey, J. (1967). Pediatric $x$-ray Diagnosis, 5th ed., p. 121. Year Book Medical Publishers, Chicago.

Capitanio, M. A., Chen, J. T. T., Arey, J. B., and Kirkpatrick, J. A. (1968). Congenital anhidrotic ectodermal dysplasia. American fournal of Roentgenology, 103, 168.

Capper, A., and Bekir, N. M. (1937). Congenital ectodermal defect. Report of 2 cases. Archives of Pediatrics, 54, 160.

Cavalli-Sforza, L. L., and Bodmen, W. F. (1971). The Genetics of Human Populations, p. 636. Freeman, San Francisco.

Clouston, H. R. (1939). The major forms of hereditary ectodermal dysplasia. Canadian Medical Association fournal, 40, 1.

Crump, I. A., and Danks, D. M. (1971). Hypohidrotic ectodermal dysplasia; a study of sweat pores in the x-linked form and in a family with probable autosomal recessive inheritance. fournal of Pediatrics, 78, 466.

De Jager, H. (1965). Congenital anhidrotic ectodermal dysplasia Case report. Fournal of Pathology and Bacteriology, 80, 321.

De Silva, P. C. C. (1939). Hereditary ectodermal dysplasia of anhidrotic type. Quarterly fournal of Medicine, 8, 97.

Drago, R. P., and Ehrenreich, T. (1961). Ectodermal dysplasia of anhidrotic type in prolonged fever in an infant. New York State Fournal of Medicine, 61, 2473.

Frankenburg, W. K., and Dodds, J. B. (1969). Denver Developmental Screening Test. University of Colorado Medical Center.

Gorlin, R. J., and Pindborg, J. J. (1964). Syndromes of the Head and Neck, p. 303. McGraw-Hill, New York. 
Gupta, B. N., and Ram, S. (1968). A case for diagnosis. Indian fournal of Pediatrics, 35, 510.

Kerr, C. B., Wells, R. S., and Cooper, K. E. (1966). Gene effect in carriers of anhidrotic ectodermal dysplasia. Fournal of Medical Genetics, 3, 169.

Lipton, I., and Roberts, M. H. (1950). Hereditary ectodermal dysplasia of the anhidrotic type. American fournal of Diseases of Children, 79, 504.

Lorber, J. (1964). Hereditary ectodermal dysplasia. Proceedings of the Royal Society of Medicine, 57, 116.

Lowry, R. B., Robinson, G. C., and Miller, J. R. (1966). Hereditary ectodermal dysplasia: symptoms, inheritance patterns, differential diagnosis, management. Clinical Pediatrics, 5, 395.

Lyon, M. F. (1971). Possible mechanisms of x-chromosome inactivation. Nature, New Biology, 232, 229.

Mathur, G. P., Gupta, M. C., and Rahl, A. H. (1967). Anhydrotic ectodermal dysplasia. Indian Pediatrics, 4, 150.

Metson, B. F., and Williams, B. K. (1952). Hereditary ectodermal dysplasia of the anhidrotic type: report of a case in a negro. Fournal of Pediatrics, 40, 303.

Mills, J. (1968). Anhidrotic ectodermal dysplasia presenting as a pyrexia of undetermined origin in the neonatal period. Postgraduate Medical fournal, 44, 193.

Misra, P. K., and Bajpai, P. C. (1969). Anhidrotic hereditary ectodermal dysplasia in four generations. Indian fournal of Pediatrics, 36, 75.
Passarge, E., and Fries, E. (1973). X-chromosome inactivation in x-linked hypohidrotic ectodermal dysplasia. Nature, New Biology, 245, 58.

Reed, W. B., Lopez, D. A., and Landing, B. (1970). Clinical spectrum of anhidrotic ectodermal dysplasia. Archives of Dermatology, 102, 134.

Singh, A., Jolly, S. S., and Kaur, S. (1962). Hereditary ectodermal dysplasia. British fournal of Dermatology, 74, 34.

Thadani, K. I. (1921). A toothless type of man: the Bhudas of India: a case of sex-linked inheritance. Fournal of Heredity, $12,87$.

Upshaw, B. Y., and Montgomery, H. (1949). Hereditary ectodermal dysplasia - a clinical and pathological study. Archives of Dermatology and Syphilology, 60, 1170.

Weech, A. A. (1929). Hereditary ectodermal dysplasia (congenital ectodermal defect): a report of two cases. American Fournal of Diseases of Children, 37, 766.

Wilkey, W. D., and Stevenson, G. H. (1945). A family with inherited ectodermal dystrophy. Canadian Medical Association Fournal, 53, 226.

Correspondence to Dr. J. B. Familusi, Department of Paediatrics, University College Hospital, Ibadan Nigeria. 